\title{
Coerção, punição e Estado ampliado no Brasil ${ }^{*}$
}

DOI: 10.15175/1984-2503-202012307

Ricardo Augusto dos Santos ${ }^{* *}$

Partidos políticos inteiros e outras organizações econômicas ou de outro gênero devem ser consideradas organismo de polícia política, de caráter investigativo e preventivo.

(GRAMSCI, 2011, p. 78).

\section{Resumo}

Forças paramilitares ilegais são grupos formados por cidadãos civis ou militares, que não integrando o exército ou a polícia, possuem estrutura, organização e armas, sendo capazes de atuar na defesa de interesses privados com objetivos políticos e financeiros. Trabalhando com a categoria de Estado Ampliado de Gramsci, procuramos demonstrar a ilusória separação entre Estado e Sociedade Civil. Através desta perspectiva, é possível investigar os atos repressivos policiais e jurídicos em conjunto. Por conseguinte, podemos afirmar que a sociedade civil não é isenta, participando da coerção através das forças ilegais, e controlando a participação política das classes.

Palavras-chave: Estado; coerção; classes sociais.

\section{Coerción, punición y Estado ampliado en Brasil}

\section{Resumen}

Las fuerzas paramilitares ilegales son grupos formados por ciudadanos civiles o militares que, pese a no formar parte del ejército o la policía, están estructurados, organizados y disponen de armas, por lo que son capaces de actuar en defensa de intereses privados con objetivos políticos y financieros. Al trabajar con la categoría de Estado ampliado de Gramsci, buscamos demostrar la ilusoria separación entre Estado y sociedad civil. A través de esta perspectiva, es posible investigar los actos represivos policiales y jurídicos en su conjunto. Por consiguiente, podemos afirmar que la sociedad civil no está al margen dado que participa en la coerción a través de las fuerzas ilegales y controla la participación política de las clases.

\footnotetext{
* Este trabalho está inserido na pesquisa de Pós-doutorado desenvolvida no Departamento de História da UFF, sob supervisão da professora doutora Gizlene Neder, com o título Coerção e Punição na República Brasileira (1922-1962).

** Pesquisador titular da Fundação Oswaldo Cruz. Doutor em História pela Universidade Federal Fluminense. Pós-Doutor em História pela Unicamp. E-mail: ricardo.augusto@fiocruz.br. http://lattes.cnpq.br/9227937026718139. (ㄴ https://orcid.org/0000-0002-7696-2420
} 
Palabras clave: Estado; coerción; clases sociales.

\title{
Coercion, punishment, and the extended state in Brazil
}

\begin{abstract}
Illegal paramilitary forces are groups formed of civilians or military civilians, which, despite not being affiliated with the army or the police, are structured, organized, and armed and able to act in defense of private interests with political and financial aims. By working with Gramsci's category of the extended state, we seek to demonstrate the illusory separation between state and civil society, with such a perspective allowing us to investigate repressive police and legal acts in tandem. Consequently, we are able to affirm that civil society is not exempt, participating in coercion by means of illegal forces and controlling the classes' political participation.
\end{abstract}

Keywords: State; coercion; social classes.

\section{Coercition, punition et État amplifié au Brésil}

\section{Résumé}

Les forces paramilitaires illégales constituent des groupes formés par des citoyens civils ou militaires qui, sans intégrer l'armée ou la police, sont dotés d'une structure, d'une organisation et d'armes leur permettant de participer à la défense d'intérêts privés avec des objectifs politiques et financiers. En nous basant sur la catégorie d'État amplifié de Gramsci, nous avons cherché à montrer le caractère illusoire de la séparation entre État et société civile. On peut, sous cette perspective, mieux étudier les actions répressives dans leur ensemble, qu'elles soient policières ou judiciaires. Nous sommes ainsi en mesure d'affirmer que la société civile n'est en rien étrangère à cet état de fait et qu'elle participe même à la coercition et au contrôle de la participation politique des différentes classes sociales par l'entremise de forces illégales.

Mots-clés : État ; coercition ; classes sociales.

\section{巴西的强制，惩罚和国家治理的扩展}

\section{摘要:}

巴西社会中存在许多非法的准军事组织，它们是由平民和退伍军人组成的团体，他们不是军队或警 察，但是具有严密的结构和军用武器，并且能够捍卫政治和经济领域的私人利益。我们使用葛兰西 (A. Gramsci) 的 “国家治理扩展” 的范畴，试图证明国家与民间社会之间的分离是虚构的。我们调 查了巴西政府的司法与警察的镇压行为，在此基础上，我们得出结论，即市民社会不是清白的，它 通过非法力量参与强制和胁迫，从而控制社会各阶级的政治参与。

关键字：国家；强制；社会阶层 
Profissionais de imprensa e pesquisadores das ciências sociais, quando analisam as condutas policiais, julgam que elas são cometidas por policiais despreparados. Porém, estes comportamentos nomeados como desastrados, são autorizadas pelo estado restrito, possuindo razões políticas e vínculos classistas. Por exemplo, as práticas, quase sempre, são dirigidas contra trabalhadores, negros e estudantes. No entanto, ainda ocorre um segundo caso de repressão a esses grupos, ampliando a opressão do estado. São as ações coercitivas executadas por forças policiais ilegais. O termo refere-se às corporações formadas por cidadãos civis ou militares, armados e investidos do poder de polícia, que mesmo não integrando o exército ou a polícia, podem possuir organização. São grupos que executam planos de segurança pública interna, sendo capazes de atuar na defesa de interesses particulares, com objetivos políticos e financeiros. Seus membros possuem experiências em grupamentos militares ou policiais.

No Brasil, entretanto, as linhas divisórias que separam as tropas estatais das organizações paramilitares são extremamente flexíveis. As forças policiais governamentais especiais realizam atos excepcionais, agindo oficialmente ou não, ultrapassando as normas legais. Além disso, não é raro, que os membros de uma tropa ilegal sejam absorvidos pelo estado restrito em suas guardas governamentais. Ainda se verifica o oposto, quando elementos dos órgãos estatais, após expulsão dos quadros de servidores, prosseguem em brutais trajetórias, almejando aumentar suas rendas através de negócios ilícitos.

Em 1831, a criação da Guarda Nacional extinguiu grupos que atuavam na defesa da ordem imperial. Em 18 de agosto daquele ano, o parlamento autorizou a criação do destacamento, substituindo os elementos que controlavam a ordem. Contudo, foi conservada a distribuição de armas aos comerciantes, apesar da nova guarnição ter incorporado as milícias paramilitares. Assim, as estruturas policiais imperiais criadas na década de 1830, foram se consolidando. Todavia, ainda sendo suplementadas por outros regimentos públicos, propiciando uma ampla rede de vigilância. No entanto, as diversas organizações policiais e militares continuaram a exercer seletivamente o domínio sobre os deserdados da terra, preferencialmente os escravos. Esses grupos eram responsáveis pelo controle dos habitantes, mantendo um ambiente propício à economia, protegendo as propriedades, imóveis e escravos. ${ }^{1}$

\footnotetext{
${ }^{1}$ Sobre polícia no período imperial, consultar Neder, Naro e Silva (1981). Ver Também, Holloway (1997).
} 
No entanto, o exemplo mais característico da via dupla de passagem entre forças ilegais e legais foram os Esquadrões da Morte. Entre as décadas de 1950 e 1970, turmas de civis, policiais e militares, formaram equipes de homens autorizados a matar em nome da lei. Durante mais de 30 anos, receberam diversos nomes. ${ }^{2}$ Neste período, a amplitude repressiva, rompendo os limites do código penal, ganhou contornos financeiros e políticos. Os conflitos entre polícia e criminosos, gerando assassinatos, envolviam também disputas comerciais. Os agentes policiais dessas organizações participavam de negócios ilícitos e cobravam suborno para não exercer fiscalização. Assim, não era um desejo de justiça que moviam esses homens. Tratava-se de um consórcio de negócios que envolviam contrabando, proteção e jogo do bicho. Também estava presente a repressão aos grupos de esquerda. ${ }^{3}$ Em suma, tratava-se de três tipos de ações. O extermínio de criminosos, o serviço de vigilância política, reprimindo os opositores da ditadura (1964-1985) e a obtenção de vantagens financeiras com o crime organizado. Destacamos que a origem dessas turmas de policiais ilegais está no quadro formado por agentes secretos mantidos com verbas que não constavam do orçamento público. Funcionando durante o Estado Novo (1937-1945), esse serviço secreto não foi encerrado com o fim da ditadura e a eleição de governos democráticos.

Não é acidental a presença de membros da Polícia Especial entre participantes dos esquadrões de extermínio. Em depoimento ao Arquivo Púbico do Estado do Rio de Janeiro, o ex-diretor do DOPS, Cecil Borer forneceu dados significativos sobre a atuação da Polícia Especial, a existência de espiões e escutas ilegais. Após a eleição de Eurico Dutra, até as chaves das salas do Partido Comunista foram obtidas: "Eu tinha a chave da porta do comitê central do partido. Íamos lá, abríamos, fiscalizávamos, fotografávamos, tirávamos tudo. Pegávamos documentos nos fichários e levávamos para o nosso arquivo". (DUARTE; ARAÚJO, 2000, p. 38). Muitos anos depois dos acontecimentos, os policiais envolvidos não negavam as ações no campo da ilegalidade em tempos democráticos. ${ }^{4}$

Em entrevista ao jornal Folha de São Paulo, Borer declarou que as casas eram invadidas sem autorização legal: "Não havia mandado de busca e apreensão, nada disso. A polícia era o poder absoluto". Sincero, comenta a parcialidade da Justiça: "No Tribunal de exceção, a priori a pessoa já estava julgada" (MAGALHÃES, 2001).

\footnotetext{
2 Serviço de Diligências Especiais, Invernada de Olaria, Homens de Ouro e Scuderie Le Cocq.

${ }^{3}$ Sobre os esquadrões da morte, consultar Antônio (2019), Verani (1996) e Jupiara e Otavio (2015).

${ }^{4}$ Sobre a utilização de agentes secretos e delatores pela polícia política durante a Era Vargas (1930-1945), consultar Florindo (2006) e Duarte e Araújo (2000).
} 
[...] os comunistas tinham uma organização, inclusive um jornal próprio, um jornal oficial. Na época em que o partido era considerado legal, a polícia se aproveitou da legalidade para saber quem eram realmente os comunistas, porque eles se declaravam abertamente. Eles abriram tudo. A polícia na época aproveitou e qualificou, fichou tudo o que pode. E esse arquivo que está aí foi decorrência disso (DUARTE; ARAUJO, 2000, p. 38). ${ }^{5}$

Estes exemplos de coexistência disciplinar estatal/miliciano são bastante esclarecedores da relação que a sociedade moderna estabeleceu com os indivíduos. Os exércitos legais atuaram à margem da constituição e do código penal. Atos de violência cometidos pelas forças estatais de repressão com motivação política não foram raros nas décadas anteriores a ditadura do Estado Novo (1937-1945), e tampouco, durante os governos posteriores a queda de Getúlio Vargas. Durante o mês de dezembro de 1935, em reunião convocada pelo Ministro da Guerra, João Gomes, o Chefe do Estado-Maior do Exército, Góis Monteiro manifestava, diante de 25 generais, sua insatisfação autoritária com os limites democráticos: "A Constituição é um obstáculo à repressão e significa impunidade, recrudescimento da desordem, a desmoralização, o caos, a anarquia, dificuldades invencíveis, até a ruína completa!" (VIANNA, 2007, p. 353). O Governo Federal não encontrou maiores dificuldades para ultrapassar os limites constitucionais, iniciando vigoroso ataque aos grupos oposicionistas, vinculados ou não a Aliança Nacional Libertadora (ANL). ${ }^{6}$

Se o crescimento da ANL havia proporcionado condições para a promulgação da Lei de Segurança Nacional, definindo crimes contra a ordem política, com a Intentona Comunista houve o auge da repressão, bastando possuir alguma proximidade com o Partido Comunista para sofrer severas punições. A Revolta de 1935 representou uma justificativa para a concentração de poder no Executivo. Durante o ano de 1936, o Congresso aprovaria medidas de exceção solicitadas por Vargas. O estado de sítio, depois de sucessivas prorrogações era substituído pelo estado de guerra. Congressistas foram presos, desrespeitando-se as imunidades parlamentares. ${ }^{7}$

\footnotetext{
${ }^{5}$ Cecil Borer entrou para a Polícia Especial aos 18 anos, em 1932. Em 1965, aposentou-se como diretor do Departamento de Ordem Política e Social (DOPS). O policial se refere ao acervo documental produzido pelas agências policiais. Estes documentos estão depositados no Arquivo Público do Estado do Rio de Janeiro.

${ }^{6}$ Em meados dos anos 1930, surgiram frentes populares compostas por correntes políticas antifascistas em vários países. No Brasil, elas reuniam desde comunistas a liberais, todos insatisfeitos com os rumos do governo Getúlio Vargas e sua aproximação com as frações de classe oligárquicas. Nos primeiros meses de 1935, os grupos descontentes com o governo começaram a promover reuniões com o propósito de fundar uma organização política. Desses encontros surgiu a Aliança Nacional Libertadora (MENDES Jr.; MARANHAO, 1981).

${ }^{7}$ Evandro Lins e Silva (ROCHA et al., 1997) concedeu um depoimento ao CPDOC, onde forneceu relevantes informações sobre o crescimento das arbitrariedades jurídicas após o início do governo constitucional de Getúlio Vargas (1934-1937).
} 
Finalmente, em 11 de setembro de 1936, era criado o Tribunal de Segurança Nacional (TSN). Até 1945, durante quase 10 anos de existência, o TSN julgou 6.998 processos envolvendo mais de 10.000 pessoas, 4.099 das quais receberam penas que variaram entre uma multa, geralmente a respeito de fraude no comércio, a até 60 anos de reclusão. ${ }^{8}$ A criação do TSN está ligada à punição dos envolvidos no levante comunista de novembro. Tribunal de exceção, inicialmente subordinado à Justiça Militar, composto por juízes civis e militares escolhidos pelo presidente da República dentre os mais reacionários. Sua função era julgar os acusados de atividades contra a segurança externa e as instituições militares e políticas. Com a implantação do Estado Novo, em 1937, o TSN abandonou a subordinação ao Superior Tribunal Militar e passou a desfrutar de uma jurisdição autônoma. Nesse período passou a condenar, não somente militantes de esquerda, mas também integralistas e políticos liberais que se opunham ao governo. De maneira semelhante ao que ocorria com a Polícia Especial, bastava uma denúncia, e o TSN condenava sem apelação. Muitas vezes, bastava uma frase contra o governo dita num bar e o "criminoso" passaria anos preso (ROCHA et al., 1997, p. 118).

A ossatura dos aparelhos coercitivos vinha obtendo uma configuração mais qualificada desde as reformas realizadas nas primeiras décadas do século. Devido ao aumento da vigilância, foi formada uma corporação para intervir em momentos tensos. A famigerada Polícia Especial foi parte desta reestruturação da Polícia. Criada em 1932, foram selecionados 150 policiais, muitos escolhidos entre atletas dos clubes cariocas. Vestiam um uniforme cáqui, usavam um boné vermelho, sendo apelidados seus integrantes de cabeças de tomate. Essa unidade foi planejada para dispersões de multidões, utilizando pelotões de choque, caminhões e motos Harley-Davidson. Composta de agentes treinados com armas potentes, cuja formação incluía a prática de esportes e lutas corporais, a Polícia Especial seria extinta em abril de 1960, quando o Distrito Federal passou a ser o Estado da Guanabara. ${ }^{9}$

Mas não eram apenas armas e capacidade física que marcavam a Polícia Especial. Seus membros deveriam apresentar um comportamento modelar, pois, se agissem como os demais policiais, não teriam o respeito da sociedade. Os componentes desse órgão, supostamente, destacar-se-iam por qualidades que provocariam admiração. Ou seja, procurou-se, dentro da Polícia Política, formar agentes especiais em condições físicas supe-

\footnotetext{
${ }^{8}$ Entre setembro de 1936 e dezembro de 1937 foram condenados 1.420 indivíduos. Cerca de três por dia. Sobre o TSN, ver Campos (1982).

${ }^{9}$ Sobre polícia na Era Vargas, consultar Cancelli (1994).
} 
riores, na medida em que seriam movidos por características excepcionais. A Polícia do Distrito Federal, desta forma, possuiria um grupo especializado para o cumprimento de missões extraordinárias. Portanto, embora tenha sido um órgão famoso pelas torturas, obteve um reconhecimento da população. Também é verdade que este simbolismo se baseou no medo pelas represálias. Bastava uma denúncia anônima para o indivíduo cair nas masmorras da Polícia Especial. Nas suas dependências, para que os gritos dos torturados não fossem ouvidos, um rádio era ligado com volume máximo. Torturados se suicidaram. Outros enlouqueceram, com sequelas para o resto da vida. ${ }^{10}$

Entendemos que a partir do final do século XIX, no Brasil, houve a expansão da sociedade capitalista burguesa, com o desenvolvimento das indústrias, aumento das ofertas de trabalho e, conseqüentemente, maior exploração do trabalhador, surgimento de agências estatais responsáveis pela gestão socioeconômica e a transição de um país agrícola para industrial. Em decorrência do desenvolvimento das relações sociais de produção capitalistas, as atividades de vigilância e repressão policial foram recebendo crescente complexidade. A partir de 1930, o projeto de modernização da Polícia - e de sua divisão política prosseguiu atualizando os serviços de vigilância com orçamento generoso e planejamento profissional. Se o projeto de especialização policial, com qualificação dos agentes, não teria mais interrupções, a transformação da polícia para um perfil técnico não representou uma diminuição das práticas arbitrárias. Ocorreu que as ações coercitivas, legais ou não, ganhavam uma dimensão mais técnica. O plano modernizador foi adquirindo consistência e provocando modificações, com o governo fornecendo às forças policiais recursos financeiros e pessoais para o desempenho de suas funções no campo oficial e ilegal. ${ }^{11}$

Em 1957, Amaury Kruel, Chefe do Departamento Federal de Segurança Pública (DFSP) aprovou a formação do Serviço de Diligências Especiais. O SDE possuía trinta funcionários selecionados por Cecil Borer. Eram agentes preparados para combater à criminalidade com ordens de eliminar os bandidos. Quase todos os policiais estiveram envolvidos em prováveis execuções, provocando o nome de batismo: Esquadrão da Morte. Segundo os jornais da época, nenhuma restrição era imposta às missões. A trajetória de violência terminou em 1959, após o assassinato do motorista da TV Tupi, caso de repercussão nega-

\footnotetext{
${ }^{10}$ Mais de sessenta anos depois das torturas que levaram Arthur Ernst Ewert à demência, Cecil Borer não esqueceu o homem que, durante meses em 1936, se negou a dar informação aos algozes: "Foi a pessoa com maior trabalho mental, determinação e inteligência que já conheci", referindo-se a Ewert por seu codinome, Harry Berger. "Altamente preparado, Berger resistiu a todo o tipo de pressão. Batiam nele o dia inteiro no convento do morro de Santo Antônio, onde estava preso, e não falava nada." (Folha de São Paulo, 13/03/2014).

${ }^{11}$ Sobre a construção da ordem burguesa, consultar Neder (2012).
} 
tiva na imprensa. O acontecimento modificou o cenário. Devido ao impacto, o grupo foi desarticulado. Porém, a lógica de atuação repressiva nas duas esferas (legal e ilegal) não desapareceu. Com a suspensão do SDE, seus policiais foram realocados em outros departamentos. Em 1962, seriam reunidos pelo governador Carlos Lacerda na Invernada de Olaria, grupo oficial subordinado aos órgãos de Segurança. Seus componentes seriam acusados dos procedimentos comuns aos grupos legais que atuavam na ilegalidade. De maneira semelhante às outras corporações especiais, ela fora concebida, em vigência do estado democrático de direito, para agir acima das normas constitucionais. ${ }^{12}$

Portanto, verificamos que as práticas ilegítimas permaneceram à frente dos órgãos policiais, possuindo uma permanência inalterável, ainda que discursos políticos liberais enfatizem, demasiadamente, as significativas mudanças que ocorreram nas relações com os cidadãos. Contudo, constatamos que as alterações políticas e administrativas não modificaram as estruturas herdadas dos órgãos extintos, nem os métodos de obtenção das informações, quase sempre à custa de arbitrariedades e torturas. ${ }^{13}$ Dentro das repartições policiais, permaneciam os funcionários e hábitos. Não havendo, inclusive, mudanças nos abusos das práticas, fosse o período democrático liberal após 1934, o Estado Novo (1937-45), Governo Dutra (1946-1951), Período JK (1956-1960) ou a Ditadura Militar (1964-1985). Segundo depoimentos dos policiais, as informações obtidas em conjunturas democráticas, portanto, em vigência do estado de direito, eram utilizadas nas épocas ditatoriais. As práticas violentas realizadas por dentro e à margem do Estado restrito, em sociedades democráticas burguesas, foram e (são) permitidas pelos órgãos estatais responsáveis pela vigilância e investigação de crimes comuns e políticos. Esta condição política possibilita constrangimentos, impedindo a livre manifestação política, que é um dos elementos do ideário democrático liberal. ${ }^{14}$

Segundo o conjunto de ideias liberais que organizam a sociedade moderna, não é o Estado que possuiu o poder legítimo e consensual para exercer força? A abdicação de poder em favor do estado não torna possível, segundo a ideologia liberal, que a socieda-

\footnotetext{
12 Reconhecido como um centro de tortura, com o golpe de 1964, a Invernada de Olaria esteve associada às ações da polícia política militar. Na década seguinte, surgiria um tripé reunindo militares, policiais e banqueiros do jogo do bicho. Sobre a repressão da ditadura militar e negócios envolvendo esses grupos, consultar Gaspari (2002), Ribeiro (1977) e Jupiara e Otavio (2015).

${ }^{13}$ Os depoimentos de policiais aposentados destacam, por exemplo, a atuação de agentes femininas seduzindo os potenciais informantes dos movimentos políticos. Sobre as práticas anticonstitucionais da polícia política em todo o período (1922-1962), consultar Duarte e Aráujo (2000).

${ }^{14}$ As forças ilegais detêm os avanços das trincheiras populares. Elas são tropas de reservas para manutenção da hegemonia.
} 
de seja controlada? De acordo com o liberalismo jurídico, o indivíduo não poderá cometer atos violentos sentindo-se supostamente ameaçado. Somente o poder estatal centralizado, através da polícia e justiça, possuiria autoridade legítima para reprimir o cidadão. Contudo, são inúmeros os casos de violação dos valores democráticos praticados por agentes policiais ou milícias armadas. Ambos, com o apoio explícito do estado (policiais, juízes e promotores), além dos intelectuais dos grupos dominantes. As práticas repressivas estatais legais e ilegais, foram e são afiançadas pelas instâncias jurídicas, permitidas e/ou toleradas pelos aparelhos policiais e jurídicos. Constitui um fato corriqueiro nas sociedades liberais democráticas que ações arbitrárias paralelas ao poder público sejam toleradas ou permitidas pelo estado restrito (Sociedade Política). São de uma exuberância trágica os números referentes as ações praticadas por grupos ilegais, exercendo o poder de polícia em sociedades modernas. ${ }^{15}$

O problema era reconstruir o aparelho hegemônico destes elementos antes passivos e apolíticos, e isto não podia acontecer sem a força: mas esta força não podia ser a 'legal'. Como em cada estado, o conjunto das relações sociais era diferente. Diferentes deviam ser os métodos políticos de emprego da força e a combinação das forças legais e ilegais. Quanto maior é a massa de apolíticos, tanto maior deve ser a contribuição das forças ilegais. Quanto maiores são as forças politicamente organizadas e educadas, tanto mais é preciso 'resguardar' o Estado legal (GRAMSCl, 2011, v. 3, p. 265).

No território nacional, somente as forças legais possuiriam a prerrogativa da utilização da violência legítima. Este é um dos fundamentos ideológicos do Estado liberal moderno: o monopólio da força. Este estatuto jurídico é concedido através das limitações impostas pelo pacto democrático, constituindo uma garantia dos direitos individuais dos cidadãos. Contudo, esse ideal de equilíbrio democrático não encontra sustentação empírica. Por exemplo, no Brasil republicano, a partir do final do século XIX, o poder de polícia, com o consequente uso da força, foi constantemente reflexo da fragilidade democrática, sendo freqüentes os abusos autoritários contra os negros, pobres, políticos de oposição. Ações ilegais cometidas sob o manto do Estado Ampliado, sendo a violência permitida e negligenciada. Nas palavras irônicas do sociólogo Paulo Sérgio Pinheiro desnudando a distância entre o direito universal preservado pelo "Leviatã" e as vidas amargas das classes subordinadas: “...loucos, prostitutas, prisioneiros, negros, hispânicos, árabes, curdos, judeus, ia-

\footnotetext{
${ }^{15}$ Evidentemente que as diferenças sociais explicam a frequência e intensidade das forças ilegais nos países dependentes do capitalismo central.
} 
nomâmis, aidéticos, homossexuais, travestis, crianças, operários irão nascer e morrer sem terem conhecido o comedimento do Leviatã" (PINHEIRO apud VALIM, 2017, p. 21). ${ }^{16}$

Nadando contra a corrente hegemônica, consideramos que, a partir do marxismo, podemos alcançar a essência dos fenômenos, demonstrando que existem vínculos entre os episódios aparentes. Geralmente, as contribuições derivadas desse conjunto de ideias em investigações sócio-históricas são menosprezadas. Vamos investigar com cuidado. Não é uma questão simples. Para uma correta apreensão dos movimentos históricos relacionais é necessário superar as aparências superficiais, entendendo o nexo dinâmico da hegemonia burguesa. ${ }^{17}$

Em 1965, surgiria um novo grupo paramilitar, a Scuderie Le Cocq. Sua origem está ligada aos policiais remanescentes da Polícia Especial. Um razoável contingente de agentes públicos desta polícia de elite participou da nova organização. Membros da PE também foram componentes do Serviço de Diligências Especiais (1957) e da Invernada de Olaria (1962). Um fato nebuloso desencadeou o surgimento da scuderie. Em 1964, durante tentativa de prisão a Manoel Moreira, o Cara de Cavalo, ocorreu o assassinato do policial Milton Le Cocq. Isso provocou um sentimento de forte indignação entre os agentes. Sua morte despertou a ira dos colegas, que se envolveram numa caçada humana. Contando com apoio da imprensa, Cara de Cavalo foi executado com dezenas de tiros. A Scuderie seria fundada no ano seguinte, com o grupo adotando como símbolo uma caveira com dois ossos cruzados e a sigla E.M. Segundo seus membros, negando a perversidade metafórica, as letras significavam uma homenagem ao Esquadrão Motorizado da Polícia Especial, a qual Le Cocq pertencera. ${ }^{18}$

Mais tarde, no final da década, aconteceu uma mudança na maneira como seriam registradas as mortes envolvendo policiais. É possível que a motivação tenha surgido devido ao número abundante de inquéritos. A iniciativa partiu do secretário de segurança pública, coronel Gustavo Borges. Um pouco antes, foram realizadas investigações das

\footnotetext{
${ }^{16}$ Leviatã diz respeito a obra de Thomas Hobbes (1588-1679). Hobbes afirmava que a guerra de todos contra todos que caracterizaria o suposto estado natural só poderia ser superado por um poder central e autoritário. O Estado seria uma espécie de monstro - o Leviatã - que concentraria o poder, controlando todas as decisões da sociedade. A transferência de força individual irracional para um poder maior seria garantia e princípio da coletividade (HOBBES, 1979).

${ }^{17}$ A leitura hegemônica da suposta oposição Coerção-Consenso vem sendo criticada por um razoável número de autores. Nas páginas de Gramsci, encontramos a riqueza conceitual das díades gramscianas. Sobre a crítica da análise dicotômica, ver Mendonça (2013).

${ }^{18}$ Lembrando que o Serviço de Diligências Especiais, onde o inspetor Le Cocq trabalhou, era chamado de Esquadrão da Morte pela imprensa. Esse policial era do grupo de motociclistas da Polícia Especial onde se tornou comandante. Sivuca entrou na Polícia Especial em 1952, chegando a presidente da Scuderie Le Cocq.
} 
torturas e assassinatos envolvendo a turma da Invernada. Inclusive, esses processos levaram à suspensão de alguns policiais. O fato é que existiu uma preocupação com as numerosas e improváveis resistências às ações dos agentes. ${ }^{19 .}$

O auto de resistência se tornou a prática corriqueira em casos de alegado confronto. ${ }^{20}$ No dia 14 de novembro de 1969 foi registrado o primeiro auto de resistência. Arlindo Coelho foi atingido pelo policial Mariel Moryiscotte (1940-1981), falecendo no hospital Miguel Couto. Arlindo teria sido surpreendido quando roubava um taxista. Um pouco antes, foi criado o Grupo Especial de Combate a Delinquência em Geral. Ficaram conhecidos como os 12 Homens de Ouro. ${ }^{21} \mathrm{O}$ grupo foi desfeito após escândalos envolvendo seus membros no crime organizado. Mariel foi condenado, chegando a cumprir pena na Ilha Grande. Sintomaticamente, dois oficiais do exército, comprometidos com a formação desses grupos, o coronel Gustavo Borges (Invernada) e o general Luís de Oliveira França (Homens de Ouro), tem seus nomes ligados a repressão dos adversários do regime militar. ${ }^{22}$

Metade homem, metade cavalo, o Centauro foi a metáfora utilizada por Antônio Gramsci (1891-1937) para ilustrar a relação entre Coerção e Consenso na sociedade burguesa. O consenso seria o domínio principal no Ocidente, ocupando um espaço característico na sociedade civil mais desenvolvida. Em decorrência deste fato, a opressão predominaria no Oriente, localizada no estado forte, em oposição à sociedade. Desta forma, a coerção estaria reservada aos momentos de crises hegemônicas das sociedades mais complexas. ${ }^{23}$

No entanto, não endossamos a perspectiva que sustenta o predomínio do estado sobre a sociedade civil. O Estado em sentido restrito não é completamente autônomo na condução das políticas repressivas frente aos trabalhadores, membros de um movimento social, pobres, negros ou estudantes. Tampouco, este estado será imparcial frente aos desmandos despóticos da sociedade. Além disso, os atos coercitivos ilegais que ocorrem

\footnotetext{
${ }^{19} \mathrm{Gramsci}$ alertava o perigo que envolve as forças ilegais. São grupos que adquirem importância à medida que o estado restrito e aparelhos de hegemonia não conseguem lidar com as crises. Com o término do trabalho sórdido, são absorvidos pelas agências coercitivas legais.

${ }^{20}$ Auto de Resistência é um procedimento administrativo no qual se registram mortes de civis por policiais, admitindo-se a resistência dos criminosos e a legítima defesa do policial.

${ }^{21}$ Os 12 homens de ouro eram Anibal Beckman dos Santos, Euclides Nascimento, Elinto Pires, Jaime de Lima, Helio Guaíba, Humberto de Matos, Lincoln Monteiro, Mariel Moryiscotte, Nelson Duarte, Neils Kaufman, José Guilherme Godinho (Sivuca) e Vigmar Ribeiro.

${ }^{22}$ Desde o dia 13 de dezembro de 1968, o país vivia sob as garras do Al-5. Congresso fechado, imprensa censurada e Habeas Corpus suspenso. O Habeas Corpus é um direito individual diante da coerção autoritária do estado.

${ }^{23}$ Antônio Gramsci advertia o equívoco de considerar como realidade a operação metodológica. “... na distinção entre sociedade política e sociedade civil, que de distinção metodológica é transformada e apresentada como distinção orgânica" (GRAMSCI, 2011, v. 3, p. 47).
} 
em democracias estáveis, períodos de transição democrática ou conjunturas autoritárias, não são cometidos, somente, devido a erros individuais. ${ }^{24}$

\begin{abstract}
O exercício 'normal' da hegemonia, no terreno tornado clássico do regime parlamentar, caracteriza-se pela combinação da força e do consenso, que se equilibram de modo variado, sem que a força suplante em muito o consenso, mas, ao contrário, tentando fazer com que a força pareça apoiada no consenso da maioria, expresso pelos chamados órgãos da opinião pública - jornais e associações -, os quais, por isso, em certas situações, são artificialmente multiplicados (GRAMSCI, 2011, v. 3, p. 95).
\end{abstract}

A hegemonia caracteriza-se pela força e persuasão, sem que uma prevaleça totalmente sobre a outra. A hegemonia não existiria sem o consenso, nem o consenso prescindiria da força. Seguindo Gramsci, a divisão operacional executada entre Estado e Sociedade situa-se numa unidade dialética em que coerção e consenso estão em equilíbrio e tensão. Trabalhando com a concepção de Estado Ampliado, a análise simplificada, segundo o qual a Sociedade Política corresponde à coerção e a Sociedade Civil à hegemonia consensual, é pulverizada, tornando-se imprescindível pensar os atos repressivos policiais e jurídicos sob outra perspectiva. Por conseguinte, através da complexidade da análise gramsciana inexiste a divisão entre as esferas. Sociedade Civil é apresentada em vários discursos políticos liberais como espaço de liberdade separado do Estado. Se esse equívoco conceitual é comum em campos liberais, ele ainda ocorre em grupos que utilizam o arsenal de Gramsci. Observamos que ele é consequência da aplicação imprópria dos conceitos, adquirindo um sentido oposto às reflexões de Antônio Gramsci. ${ }^{25}$

Os conceitos Estado e Sociedade Civil, além da vinculação intrínseca e relacional, estão inseridos nas relações sociais. Assim, a partir de investigações empíricas, dois fenômenos sociais podem ser observados: A coerção realizada às margens da lei contra as classes subordinadas e o acontecimento desses atos em democracias ou transições democráticas conservadoras. Conjunturas que, segundo ideias liberais, estariam livres dos atos opressivos que impossibilitam a livre manifestação. Nestes períodos democráticos,

\footnotetext{
${ }^{24} \mathrm{O}$ arcabouço jurídico autoriza o controle, preservando a justificativa da desigualdade e exploração. Têmis, a divindade grega, representando a justiça, é personificada de olhos vendados.

${ }^{25}$ Essa conceituação errônea de sociedade civil é hegemônica no senso comum, na imprensa, nos intelectuais liberais e vigora em alguns grupos marxistas. No âmbito das ciências sociais, investigações nãomarxistas e marxistas consideram que as posições (Coerção e Consenso) são distintas e antagônicas durante a dominação que as classes e frações burguesas exercem sobre o conjunto das classes trabalhadoras. Alertamos que esta análise é equivocada, não correspondendo a matriz gramsciana. Além de ignorar condições históricas concretas específicas.
} 
as câmaras de representantes eleitos pela população e tribunais funcionariam independentemente. Sindicatos, partidos e imprensa também não sofreriam constrangimentos. ${ }^{26}$

\begin{abstract}
Violência não é fenômeno estranho na sociedade burguesa. Ela faz parte do cotidiano. Nas situações de pretensa normalidade democrática, quando a hegemonia burguesa parece alcançar consenso generalizado, as classes subordinadas e exploradas podem até não ter a percepção dessa violência, porque ela se dilui, se manifesta somente em episódios eventuais, se conserva latente como ameaça. Mas, ela ainda existe, pois sem o exercício do poder coercitivo não existiria o Estado burguês (GORENDER, 1987, p. 226).
\end{abstract}

A análise dicotômica (Estado $X$ Sociedade) desconsidera a requintada perspectiva das Díades Gramscianas, inserindo em lugar das complexas determinações históricas, falsos antagonismos entre Sociedade Civil e Sociedade Política ou Ditadura e Democracia. A leitura cuidadosa de Gramsci proporciona uma crítica à interpretação ilusória dessa oposição entre Coerção e Consenso. Todavia, ainda é absolutamente necessário o confronto com a observação histórica. A análise marxista ultrapassa a aparência, mas sem a concretude dos fatos, estaremos reduzidos a metafísica. A análise concreta exige pesquisa de caso concreto.

De uma classe social revolucionária, a burguesia, entre o século XVIII e a primeira metade do século XIX, integrou grupos sociais às novas relações capitalistas, passando a comportar-se como uma classe reacionária, cujo interesse era manter as condições permanentes de reprodução e desenvolvimento das relações sociais capitalistas. As frações de classe burguesas revolucionárias reconheciam interesses em comum entre os novos grupos sociais. Entretanto, a partir do momento em que as classes possuidoras do capital assumiram as funções de comando, a relativa identidade desapareceu. Para a burguesia obter domínio estável nas sociedades modernas foi necessário a difusão permanente da igualdade democrática. A exploração capitalista, com a desigualdade resultante dela, seria, doravante, constantemente velada. Este (é) foi um dos elementos ideológicos principais para a construção hegemônica da sociedade liberal. Em suma, as ideologias que negam as relações de exploração e os conflitos inerentes às desigualdades, propagam visões universais e harmônicas das relações capitalistas. Portanto, para garantir a hegemonia é necessário à burguesia o monopólio dos aparelhos ideológicos que difundem a

\footnotetext{
${ }^{26} \mathrm{O}$ Estado capitalista não é árbitro imparcial das lutas sociais e, portanto, não pode ser analisado isoladamente, desvinculado da conjuntura histórica.
} 
propaganda do consenso idílico. No contexto das revoluções do século XVIII, a burguesia era partidária da igualdade política, mas estava distante da igualdade social. ${ }^{27}$

Portanto, Consenso e Coerção representam uma defesa contínua dos interesses burgueses no estado capitalista. Para a eficácia desse projeto, é necessário a manutenção de potencial opressivo. No entanto, esse substancial papel coercitivo nas sociedades democráticas carece de sustentação consensual. Para que a burguesia obtenha a concordância das classes trabalhadoras para o domínio burguês, em que os interesses opostos são edulcorados, é inexorável obstruir a organização dos trabalhadores e a formação de aparelhos contra-hegemônicos. ${ }^{28}$ Também é necessário o convencimento sobre a necessidade de repressão para a segurança da sociedade.

Em momentos de menor exploração dos trabalhadores, os elementos coercitivos teriam menos peso, tendo primazia o encaminhamento do consenso. A coerção, nesses momentos, poderá ser dirigida aos setores mais combativos. Também existirá a criminalização das "classes perigosas", legitimando a prisão dos suspeitos. Nas etapas de ínfima resistência, em que a coerção possuiria suficiente, mas reduzida intensidade, a burguesia controlaria a classe trabalhadora utilizando instrumentos ideológicos, sustentando os interesses classistas. Contudo, apoiado nas lutas sociais, os trabalhadores podem superar os limites opressivos, dirigindo a construção dos aparelhos ideológicos classistas e organizando os subordinados, ameaçando à predominância dos interesses burgueses. Neste momento, surge a agressão sem freios. Estará autorizado o desequilíbrio, ganhando impulso a violência nas relações sociais.

Se a capacidade de organização dos trabalhadores ameaçar a hegemonia burguesa, as classes dominantes buscarão amparo nas ditaduras, rompendo o pacto liberal democrático. Desta maneira, a repressão, latente nos momentos de aparente diminuição da luta de classes, represará as classes subordinadas. Assim, a coerção (diluída ou não) constitui a fronteira da dominação burguesa, se inserindo, inclusive nos momentos de predomínio consensual, como barreiras da ordem social, colunas burguesas frente aos subordinados. ${ }^{29}$

\footnotetext{
${ }^{27}$ Outro dado aponta que nas regiões europeias onde a burguesia desenvolveu-se tardiamente, ela era suficientemente conservadora/autoritária.

${ }^{28}$ A crença de uma sociedade civil separada do estado, que estaria sendo ameaçada, é ilusória. A agressão é autorizada, sendo mesmo reivindicada pela chamada Sociedade Civil.

${ }^{29}$ Convém assinalar que os recursos metodológicos analíticos procuram reconstruir a totalidade da vida social. Assim, não ignoramos que, além das práticas coercitivas e ideológicas, a dominação burguesa hegemônica propicia também concessões materiais positivas, que são negociadas entre o Capital e as classes subalternas.
} 
É fundamental realçar, mais uma vez, que coerção e consenso não são condições opostas e inconciliáveis. Tanto a força está presente na dominação baseada, predominantemente, no consenso, quanto, nos momentos de ruptura do contrato democrático, retornam os mecanismos coercitivos, intrínsecos, antes dissimulados. Enquanto a persuasão se mostrar suficiente para a reprodução das relações sociais, a coerção será menor, mas envolta sob consenso. Mesmo nos períodos de hegemonia, nenhuma classe abdicará totalmente da violência, observando-se, inclusive, um aumento dos conflitos sociais em conjunturas democráticas. Em circunstâncias de afirmação hegemônica das classes dominantes, encontraremos, portanto, maior risco do recurso a violência (PORTELLI, 1977, p. 63).

Lênin, em debate com Kautsky, afirmava que quanto mais desenvolvida a democracia, mais provável se encontrará a possibilidade da guerra civil. Portanto, diante das possíveis ameaças à hegemonia burguesa não são toleradas manifestações contrárias ao domínio classista. Além disso, a violência simbólica, ameaçando uso da agressão, integrará uma pedagogia da violência. Uma prevenção à ordem.

Não há estado, nem mesmo o mais democrático, onde não haja escapatórias ou
reservas nas constituições que assegurem à burguesia a possibilidade de lançar
as tropas contra os operários, declarar o estado de guerra... em caso de violação
da ordem... como fazem os burgueses mais democráticos e republicanos na Amé-
rica ou na Suíça contra os operários em greve (LÊNIN, 2004, p.17).

Evidentemente, não estamos ignorando as inúmeras diferenças entre os governos democráticos e ditatoriais. No estado de direito, ainda que existam limites a participação política, mesmo com a desigualdade social proporcionada pela exploração, as fronteiras democráticas asseguram uma contenção das arbitrariedades. Ainda que direitos fundamentais fiquem ameaçados, existirá um controle impedindo a violação das normas sociais. Nas ditaduras, elas são descartadas. Não obstante, é necessário assinalar que as formas políticas e administrativas modernas surgiram após as transformações sociais ocorridas após o declínio da formação social medieval. Com as Revoluções, Industrial e Francesa, as ordens sociais ficaram superadas por novas classes sociais, modificando as relações de poder. Sob o império das relações sociais capitalistas a coação econômica tornou-se determinante para o funcionamento do mundo do trabalho, mas a coerção física e simbólica ainda seria fundamental para a manutenção da ordem e controle do trabalhador. ${ }^{30}$

\footnotetext{
${ }^{30}$ Marx chamou a opressão exercida pelas relações econômicas de coerção muda. Ele destacou momentos em que a violência desempenhou papel preponderante na história. A separação compulsória dos produtores de seus meios de subsistência, com sua consequente proletarização, e a permanência dessa expropriação.
} 
Ao cabo de nossos argumentos, contatamos que as formulações clássicas do liberalismo democrático escamoteiam a face autoritária desde o início e desenvolvimento das relações sociais capitalistas. Após o período das transformações operadas no final do século XVIII, abriu-se uma época de crescente abandono por parte das frações burguesas dos ideais de liberdade e igualdade. Esses grupos sociais viram-se diante de um novo momento histórico. Doravante seriam parte do conflito envolvendo antigas classes buscando restaurar privilégios e proletários reivindicando amparo social. ${ }^{31}$

Prosseguindo com o exame da dominação burguesa, ainda encontramos os seguintes fatos. Em determinadas conjunturas, após períodos ditatoriais, a coerção estará diluída ideologicamente, constituindo um suporte hegemônico das classes burguesas, endossando a participação das demais classes sociais no projeto político liberal. Este fenômeno ocorreu na redemocratização após o Estado Novo e, posteriormente, na transição conservadora em seguida a queda da ditadura implantada em 1964. Dessa forma, a presença da coerção latente, em períodos democráticos, constitui uma estratégia política. A repressão exercida pelos aparelhos e agentes sociais (ilegais ou não), através da violência legitimada e tolerada será parte da hegemonia.

Por conseguinte, mesmo que na democracia liberal burguesa, a hegemonia de uma classe se exerça consensualmente, guardando-se a violência para os momentos de crise, ocorrerá que, em alguns períodos específicos dessa dominação, como o período Dutra (1945-1951), o uso/ameaça da força legal (ou ilegal) assumirá um perfil funcional. Isto é, o presumido caráter acidental da agressão estará ativo.

Não é o capital, mas o estado, que conduz o conflito de classes quando ele rompe
as barreiras e assume uma forma mais violenta. O poder armado do capital geral-
mente permanece nos bastidores; e, quando se faz sentir como força coercitiva
pessoal e direta, a dominação de classe aparece disfarçada como um estado 'au-
tônomo' e 'neutro' (WOOD, 2011, p. 47).

Seria uma ilusão acreditar em ausência de repressão nas democracias liberais. No máximo, existirá um controle institucional diante das iniquidades, tentando preservar os direitos individuais. Evidentemente, que em democracias existem direitos políticos do cidadão. Não podemos rejeitar isso. No entanto, consideramos que para a manutenção da

Ele diz: "E a história dessa expropriação está gravada nos anais da humanidade com traços de sangue e fogo" (MARX, 2013, p. 787).

${ }^{31}$ Em plena Revolução Francesa, a burguesia combatia a organização dos trabalhadores (MARX, 2013). Em meados do século XIX, as frações de classe burguesas não ocultavam mais seus objetivos. Sobre os movimentos contrarrevolucionários do século XIX, consultar Macpherson (1979) e Hobsbawm (1982). 
hegemonia burguesa, a coerção, ou ameaça simbólica de uso, nunca é abandonado. Também é fato que nas democracias de longa tradição, os aparelhos de repressão possuem uma continuidade centenária, não sendo exclusividade das sociedades dependentes ou de formação tardia do capitalismo. Concordando com esta observação, até o pensamento liberal reconhecerá que a violência policial repressiva não é um fenômeno exclusivo de períodos especiais nas sociedades ocidentais. Ela está presente estrategicamente, sendo parte integrante das sociedades de classes.

Procuramos apresentar dois aspectos. O primeiro afirma que, mesmo nas conjunturas de predominância de consenso entre as classes sociais, a coerção está presente. 0 segundo trata de realçar que a repressão poderá ser exercida por forças policiais, estatais ou privadas, ilegais, que embora ilegítimas sob o contrato democrático, estarão autorizadas pelo Estado Ampliado. Portanto, afastando as impressões aparentes, consideramos que o julgamento das épocas democráticas, ou dos períodos de transição conservadora rumo ao Estado de Direito, como tempos ausentes de violência, é obra do pensamento político dominante. Não apresento aspectos conclusivos, mas uma visão crítica do tema, situando-o historicamente e sugerindo perspectivas que julguei relevantes, principalmente em torno de questões principais. A violência nas ações repressivas são estratégias de controle social e assumem na sociedade burguesa a função política de preservar a hegemonia consensual armada de coerção. Consenso este construído a partir dos aparelhos privados de hegemonia, através dos intelectuais que formulam e difundem a visão da classe hegemônica. ${ }^{32}$

Jamais a violência exercida contra as classes dominadas estará apartada, apresentando uma regularidade pouco modificada pelas formas que as instituições políticas assumem, principalmente quanto ao estado restrito, que nunca abandona, mesmo nos momentos de autoritarismo diluído, aos instrumentos com que é dotado nas ditaduras. Com meios jurídicos autorizando, ou não, os atos coercitivos nunca são interrompidos. São aperfeiçoados e utilizados. Se em pleno estado de direito, as garantias constitucionais das classes subordinadas poderão ser violadas, em anos de governo arbitrário, o desrespeito será a regra. Consideramos que o arsenal de leis e práticas utilizadas nos porões das ditaduras se mantém com vigor para defender as frágeis democracias, não somente aceitando a repressão como necessitando dos instrumentos de exceção para seu governo. ${ }^{33}$

\footnotetext{
32 Sobre a adoção das teorias de matriz gramsciana para estudar o estado no Brasil, ver Mendonça (2005).

${ }^{33}$ Sobre a polícia política em tempos democráticos, consultar Reznik (2004), Rose (2017) e Pomar (2002).
} 
A força física e/ou simbólica do Estado assume um papel na manutenção hegemônica. Existe uma convergência nas ciências sociais de que, durante a hegemonia burguesa, o uso da violência, quando imprescindível, dado uma ocasional necessidade, necessitará ser autorizada legalmente para se efetivar. Contudo, coletando dados empíricos, e adotando perspectivas marxistas, constatamos que as alternativas- democracia, ditadura - são formas transitórias de dominação, portanto não prescindem de opressão para manter seus domínios, ultrapassando, assim, o caráter emergencial da força.

Poderíamos argumentar, tentando estabelecer uma hipótese contrária, indagando se as ocorrências coercitivas e realizadas à margem dos códigos penais e constituições, não constituem apenas acontecimentos ocasionais sem articulação? Poderíamos afirmar a inexistência de relação entre os fatos políticos e as ações policiais estatais/milícias armadas, tornando-se acontecimentos fortuitos e isolados. Os assassinatos, torturas e crimes praticados seriam ações levianas?

Poderíamos ainda, buscando atenuar ou negar a hipótese central, que estes fenômenos constituem fatos indeterminados, não constituindo um objeto a ser estudado. Porém, isto é falso. Nas democracias liberais democráticas, a coerção aos movimentos políticos não é um acontecimento extraordinário ou reservado a momentos de crise hegemônica. No máximo, a coerção física e/ou simbólica será objeto de manipulação nas lutas ideológicas, procurando ocultá-la. ${ }^{34}$ Se for correto que a dominação se apoia em ações educativas e culturais, e não somente em atitudes coercitivas para a manutenção hegemônica, poderíamos, com ironia, afirmar que a sociedade civil não está isenta. Ela exerce a coerção, dirigindo a participação política das classes.

As condutas policiais são adequadas às estruturas de poder classistas e são possíveis de apreensão analítica para o conhecimento do exercício de poder nas sociedades. A origem da metáfora do Centauro está em Maquiavel. Ele recomendava ao Príncipe possuir essa natureza. Ser mitológico, meio fera, meio homem. Essa ambigüidade seria utilizada por Gramsci para demonstrar a relação entre consenso e coerção. Esse duplo vínculo, animal-homem, significa que o príncipe deve comportar-se de acordo com as circunstâncias. A comparação é valiosa para investigar a dominação política, pela estratégia do consenso ou por intermédio da força. As ditaduras seriam a última estratégia do governante: A violência sem limites procurando uma legitimidade perdida.

${ }^{34}$ Sobre a perseguição dos trabalhadores pela polícia política no período Dutra, consultar Pereira (2004). 


\section{Referências}

ANTONIO, Mariana Dias. Disparos na cena do crime: o Esquadrão da Morte sob as lentes do Última Hora Carioca (1968-1969). São Paulo: Intermeios, 2019.

CAMPOS, Reynaldo Pompeu de. Repressão judicial no Estado Novo: esquerda e direita no banco dos réus. Rio de Janeiro: Achiamé, 1982.

CANCELLI, Elizabeth. O mundo da violência: a polícia na Era Vargas. Brasília: UNB, 1994.

DUARTE, Leila Menezes; ARAUJO, Paulo Roberto Pinto de. A contradita: polícia política e comunismo no Brasil - 1945-1964. Rio de Janeiro: Arquivo Público do Rio de Janeiro, 2000.

FLORINDO, Marcos Tarciso. O Serviço Reservado da Delegacia de Ordem Política e Social de São Paulo na Era Vargas. São Paulo: UNESP, 2006.

GASPARI, Elio. A ditadura envergonhada. São Paulo: Companhia das Letras, 2002.

GRAMSCI, Antônio. Cadernos do Cárcere. Rio de Janeiro: Civilização Brasileira, 2011. v. 3.

GORENDER, Jacob. Combate nas trevas: a esquerda brasileira: das ilusões perdidas à luta armada. São Paulo: Ática, 1987.

HOBSBAWM, Eric. A era do capital: 1848-1875. Rio de Janeiro: Paz e Terra, 1982.

HOBBES, Thomas. Leviatã ou matéria, forma e poder de um Estado eclesiástico e civil. São Paulo: Abril Cultural, 1979.

HOLLOWAY, Thomas H. Polícia no Rio de Janeiro: repressão e resistência numa cidade do século XIX. Rio de Janeiro: Fundação Getúlio Vargas, 1997.

JUPIARA, Aloy; OTAVIO, Chico. Os porões da contravenção: jogo do bicho e ditadura militar: a história da aliança que profissionalizou o crime organizado. Rio de Janeiro: Record, 2015.

LÊNIN, Ilyich Ulianov. Obras Escolhidas. São Paulo: Alfa-Omega, 2004. v. 3.

MACPHERSON, Crawford Brough. A teoria política do individualismo possessivo de Hobbes a Locke. Rio de Janeiro: Paz e Terra, 1979.

MAGALHÃES, Mário. Ex-diretor revela como era a espionagem. FSP, São Paulo, 15 abr. 2001. Disponível em: https://www1.folha.uol.com.br/folha/brasil/ult96u18449.shtml. Acesso em: 12 abr. 2019.

MARX, Karl. O capital: crítica da economia política. São Paulo: Boitempo, 2013. livro 1.

MENDES JR., Antônio; MARANHÃO, Ricardo. Brasil História, texto e contexto: Era de Vargas. São Paulo: Brasiliense, 1981. 
MENDONÇA, Sônia Regina de (Org.). O Estado brasileiro: agentes e agências. Niterói: EdUFF/Vício de Leitura, 2005.

MENDONÇA, Sonia Regina de. Sociedade civil em Gramsci: venturas e desventuras de um conceito. In: PAULA, Dilma Andrade de; MENDONÇA, Sonia Regina de (Org.). Sociedade civil: ensaios históricos. Jundiaí: Paco Editorial, 2013. p. 7-25.

NEDER, Gizlene. Discurso jurídico e ordem burguesa no Brasil: criminalidade, justiça e constituição do mercado de trabalho (1890-1927). Niterói: Eduff, 2012.

NEDER, Gizlene; NARO, Nancy; SILVA, José Luiz Werneck da. A polícia na Corte e no Distrito Federal - 1831-1930. Rio de Janeiro: PUC-RIO, 1981. Série Estudos, n. 3.

PEREIRA, Luciana Lombardo Costa. Polícia Política e caça aos comunistas: repressões e pressões sobre o movimento operário no Rio de Janeiro (1945-1964). In: MATTOS, Marcelo Badaró. Trabalhadores em greve, polícia em guarda: greve e repressão policial na formação da classe trabalhadora carioca. Rio de Janeiro: Bom Texto, 2004. p. 161199.

POMAR, Pedro Estevam da Rocha. A democracia intolerante: Dutra, Adhemar e a repressão ao Partido Comunista (1946-1950). São Paulo: Imprensa Oficial do Estado, 2002.

PORTELLI, Hugues. Gramsci e o bloco histórico. Rio de Janeiro: Paz e Terra, 1977.

REZNIK, Luís. Democracia e segurança nacional: a polícia política no pós-guerra. Rio de Janeiro: FGV, 2004.

RIBEIRO, Octávio. Barra pesada. Rio de Janeiro: CODECRI, 1977.

ROSE, Robert Sterling. O Homem mais perigoso do país: biografia de Filinto Muller - O temido chefe de polícia da ditadura Vargas. Rio de Janeiro: Record, 2017.

ROCHA, Dora et al. O salão dos passos perdidos: depoimento ao CPDOC. Rio de Janeiro: Nova Fronteira/CPDOC, 1997.

VALIM, Rafael. Estado de exceção: a forma jurídica do neoliberalismo. São Paulo: Contracorrente, 2017.

VERANI, Sergio. Assassinatos em nome da lei. Rio de Janeiro: Aldebarã, 1996.

VIANNA, Marly de Almeida Gomes. Revolucionários de 1935: sonho e realidade. São Paulo: Expressão Popular, 2007.

WOOD, Ellen Meiksins. Democracia contra capitalismo: a renovação do Materialismo Histórico. São Paulo: Boitempo, 2011. 